a penicillamine-induced immune complex nephropathy (Tribe et al., 1974).

The mode action of penicillamine in R.A. is unknown. Thymus-derived lymphocytes are known to play an important part in the pathogenesis of autoimmune diseases, including R.A. In view of the finding of pathological changes in the thymus in $70-80 \%$ of patients with myasthenia gravis the effect of penicillamine in apparently precipitating myasthenia gravis in R.A. may therefore be of more than anecdotal interest.

We thank Dr. J. A. Cosh, consultant physician, Royal National Hospital for Rheumatic Diseases, Bath, for permission to publish details of case 1 ; Dr. G. S. Wakefield, consultant neurologist, Royal United Hospital, Bath, and Dr. G. D. Walker, general practitioner, for helpful information regarding case 2; Dr. K. J. Zilkha, consultant neurologist, National Hospital for Nervous Diseases, Queen Square, London, for helpful information and advice regarding case 3; and Dr. J. A. S. Davis, registrar in neurology at Chase Farm Hospital, Enfield, for his advice with case 4.

\section{ADDENDUM}

In case 3 pyridostigmine was subsequently withdrawn without any recurrence of myasthenic symptoms.

\section{References}

Bloch, K. J., et al. (1965). Medicine, 44, 187.

Bröll, H. (1974). Penicillamine: An International Symposium. Royal Society of Medicine. In preparation.

Camus, J. P. (1974). Penicillamine: An International Symposium, Royal Society of Medicine. In preparation.

Society of Medicine. In prepara:
Davies, J., et al. (1974). In Press.

Downes, J. M., Greenwood, B. M., and Wray, S. H. (1966). Quarterly Downes, J. M., Greenwood, B.

Fournal of Medicine, 35, 85.
Graaff, $\mathrm{R}$ de (1962) De Rheumatoide Arthritis in Nederland. Thesis, Leiden.

Huskisson, E. C., et al. (1974). Annals of Rheumatic Diseases, 33, 532

Lyle, W. H. (1974). Personal communication.

Miehlke, K. (1974). Penicillamine: An International Symposium. Royal Society of Medicine. In preparation.

Multicentre Trial Group (1973). Lancet, 1, 275.

Oosterhuis, H. J. G. H., and de Haas, W. H. D. (1968). Acta Neurologica Scandinavica, 44, 219.

Oosterhuis, H. J. G. H., and de Haas, W. H. D. (1969). Acta Rheuma-

tologica Scandinavica, $15,54$.
Ott, V. R. (1974). Penicillamine: An International Symposium. Royal Society of Medicine. In preparation.

Ropes, M. W., et al. (1959). Annals of the Rheumatic Diseases, 18, 49

Simpson. J. A. (1966). Annals of the New York Academy of Sciences, 135 506.

Simpson, J. A. (1974). Disordors of Voluntary Muscle, ed. J. N. Walton, p. 654. London, Churchill Livingstone.

Tribe, C. R., Mackenzie, J. C., and Bacon, P. A. (1974). Penicillamine: An International Symposium. Royal Society of Medicine. In preparation Wright, E. A., and McQuillen, M. P. (1971). Annals of the New York Academy of Sciences, 183, 358.

\title{
Changes in Haemoglobin Binding Curve and Oxygen Transport in Chronic Hypoxic Lung Disease
}

\author{
D. C. FLENLEY， L. J. FAIRWEATHER， N. J. COOKE， B. J. KIRBY
}

British Medical fournal, 1975, 1, 602-604

\section{Summary}

Direct measurements of the factors determining blood oxygen transport in 10 patients with chronic hypoxic respiratory failure led to the conclusion that wide differences in the position of their oxygen binding curves, due to spontaneous differences in red-cell 2, 3-diphosphoglycerate, had little effect on oxygen delivery to the tissues, as assessed by the mixed venous oxygen tension when they were breathing air. This result arises from the shape of the oxygen binding curve. A drug which could shift the curve to the right would help tissue oxygenation in cardiogenic and other forms of shock, when a low cardiac output can not be improved though arterial blood can be well oxygenated.

\section{Introduction}

The discovery that variations in red-cell concentrations of 2, 3-diphosphoglycerate (2,3-DPG) could alter the affinity of haemoglobin for oxygen (Benesch and Benesch, 1967; Chanutin and Curnish, 1967) has led to intensive study of the binding of ligands to the haemoglobin molecule (Kilmartin and RossiBernardi, 1973). Nevertheless, less attention has been paid to the effects of variations in $2,3-D P G$ concentrations on oxygen

University Department of Medicine, Royal Infirmary, Edinburgh EH3 9YW

D. C. FLENLEY, PH.D., F.R.C.P., Reader in Medicine

L. J. FAIRWEA THER, B.SC., PH.D., Faculty of Medicine Research Scholar N. J. COOKE, M.B., M.R.C.P., Research Fellow (Present appointment: Senio N.J. COOKE, M.B., M.R.C.P., Research Fell

B. J. KIRBY, M.B., M.R.c.P., Lecturer (Present appointment: Senior B. J. KIRBY, M.B., M.R.C.P., Lecturer (Present app
Lecturer, Exeter Postgraduate Medical Centre, Exeter) transport in vivo, particularly in patients with hypoxaemia resulting from chronic lung disease. Transport of oxygen by the blood depends on the concentration of haemoglobin, the arterial oxygen tension $\left(\mathrm{PaO}_{2}\right)$, arterial $\mathrm{pH}$, and the cardiac output in addition to the oxygen binding curve. The position of this curve can be described by the oxygen tension necessary to obtain $50 \%$ full saturation $\left(P_{50}\right)$. We have measured all these variables in 10 hypoxaemic patients during right heart catherization to assess the effects of their different 2, 3-DPG levels on oxygen transport.

\section{Patients and Methods}

We studied 10 patients aged from 43 to 70 years, who were in a stable state of chronic hypoxaemia (mean $\mathrm{PaO}_{2}$ ( \pm S.D.) $6.4 \pm 1.03 \mathrm{kPa}$ $(48.1 \pm 7.7 \mathrm{~mm} \mathrm{Hg})$ ), with different levels of chronic $\mathrm{Co}_{2}$ retention $\left(\mathbf{P a C O}_{2} 7.3 \pm 1.6 \mathrm{kPa}(54.9 \pm 11.9 \mathrm{~mm} \mathrm{Hg})\right)$. All had irreversible airways obstruction $\left(\mathrm{FEV}_{1} 0.49 \pm 0.21 \mathrm{l}, \mathrm{FEV} \% 33 \cdot 7 \pm 11.0 \%\right)$ and hyperinflation of the lungs (residual volume $66 \cdot 5 \pm 10 \cdot 6 \%$ of total lung capacity). This confirmed the clinical diagnosis of cor pulmonale (pulmonary arterial mean pressure $4.8 \pm 1.5 \mathrm{kPa}(35.8 \pm 11.5 \mathrm{~mm} \mathrm{Hg})$ ) resulting from chronic bronchitis and emphysema, with different degrees of secondary polycythaemia (red cell mass $51 \cdot 4 \pm 19.5 \mathrm{ml} / \mathrm{kg}$ ). Right heart catherization and the other measurements were part of their assessment for long-term domiciliary oxygen therapy, and all patients gave informed consent to the procedures after the study had been approved by the local ethical committee.

When the patients were resting supine and breathing air simultaneous blood samples were taken from catheters in the brachial and pulmonary arteries, and oxygen uptake, by collection and analysis of expired gas, and cardiac output (green dye dilution) were measured. Blood gas tensions and pH were measured by IL 113 electrodes calibrated with tonometered blood (Flenley et al., 1967); oxygen capacity by spectrophotometry (King and Wooton, 1956) calibrated against the method of Van Slyke and Neill (1924); $P_{50}$ by a modification of the mixing technique (Edwards and Martin, 1956); red-cell mass by ${ }^{51} \mathrm{Cr}$ dilution; and 2,3-DPG by a modification of Krimsky's (1963) enzymatic assay. Details of these methods and their precision are given by Fairweather et al. (1974). 
Measured and Calculated Indices of Oxygen Transport in 10 Patients with Respiratory Failure.

\begin{tabular}{|c|c|c|c|c|c|c|c|c|c|}
\hline \multirow[b]{2}{*}{$\begin{array}{l}\text { Case } \\
\text { No. }\end{array}$} & \multirow[b]{2}{*}{$\begin{array}{c}P_{50}(7 \cdot 4) \\
(\mathrm{kPa})\end{array}$} & \multirow{2}{*}{$\begin{array}{c}2,3-D P G \text { in } \\
\text { Red Cells } \\
\left.\times 10^{-6} \mathrm{~mol} / \mathrm{g} \mathrm{Hb}\right)\end{array}$} & \multicolumn{3}{|c|}{ Arterial Blood } & \multirow[b]{2}{*}{$\begin{array}{l}\text { Cardiac Output } \\
(1 / \mathrm{min})\end{array}$} & \multirow[b]{2}{*}{$\begin{array}{l}\text { Oxygen Uptake } \\
(\mathrm{ml} / \mathrm{min})\end{array}$} & \multicolumn{2}{|c|}{ Mixed Venous Blood } \\
\hline & & & $\underset{(\mathbf{k P a})}{\mathrm{Po}_{2}}$ & $\mathrm{pH}$ & $\begin{array}{l}\text { Oxygen Capacity } \\
\text { of } \\
\text { Arterial Blood } \\
\text { (ml/l) }\end{array}$ & & & $\underset{\text { pH }}{\text { Venous }}$ & $\begin{array}{l}\mathrm{P} \mathrm{PzO}_{2} \\
(\mathrm{kPa})\end{array}$ \\
\hline $\begin{array}{r}1 \\
2 \\
3 \\
4 \\
5 \\
6 \\
7 \\
8 \\
9 \\
10\end{array}$ & $\begin{array}{l}3.42 \\
3.60 \\
3.69 \\
3.64 \\
3.64 \\
3.81 \\
3.40 \\
3.53 \\
3.11 \\
3.46\end{array}$ & $\begin{array}{l}16.1 \\
16.0 \\
18.9 \\
14.7 \\
18.3 \\
19.1 \\
12.6 \\
13.5 \\
13.2 \\
18.1\end{array}$ & $\begin{array}{l}5 \cdot 1 \\
8 \cdot 7 \\
5 \cdot 7 \\
6 \cdot 0 \\
5 \cdot 2 \\
7 \cdot 1 \\
5.9 \\
5 \cdot 7 \\
6 \cdot 3 \\
7 \cdot 2\end{array}$ & $\begin{array}{l}\mathbf{7 . 4 5} \\
\mathbf{7 . 4 4} \\
\mathbf{7 . 4 2} \\
\mathbf{7 . 3 3} \\
\mathbf{7 . 3 5} \\
\mathbf{7 . 3 7} \\
\mathbf{7 . 3 7} \\
\mathbf{7 . 3 5} \\
\mathbf{7 . 3 6} \\
\mathbf{7 . 4 0}\end{array}$ & $\begin{array}{l}231 \\
240 \\
208 \\
233 \\
212 \\
175 \\
243 \\
197 \\
186 \\
221\end{array}$ & $\begin{array}{l}9 \cdot 42 \\
6 \cdot 17 \\
5.67 \\
6 \cdot 10 \\
5.03 \\
7.39 \\
6.34 \\
7.47 \\
5.29 \\
3.75\end{array}$ & $\begin{array}{l}184 \\
260 \\
205 \\
251 \\
201 \\
153 \\
325 \\
313 \\
242 \\
224\end{array}$ & $\begin{array}{l}7 \cdot 39 \\
7 \cdot 38 \\
7 \cdot 41 \\
7 \cdot 30 \\
7 \cdot 34 \\
7 \cdot 36 \\
7 \cdot 36 \\
7 \cdot 31 \\
7 \cdot 35 \\
7 \cdot 39\end{array}$ & $\begin{array}{l}4 \cdot 7 \\
5 \cdot 6 \\
4 \cdot 3 \\
4 \cdot 5 \\
3 \cdot 7 \\
5 \cdot 6 \\
4 \cdot 3 \\
4 \cdot 3 \\
4 \cdot 0 \\
4 \cdot 8\end{array}$ \\
\hline
\end{tabular}

Conversion: SI to Traditional Units- $\mathrm{kPa} \approx 7.5 \mathrm{~mm} \mathrm{Hg}$.

\section{Results}

$P_{50}$ was expressed at $\mathrm{pH}$ of $7 \cdot 40$ using a Bohr effect of $-0 \cdot 50$, the actual arterial $\mathrm{pH}$ varying only between $7 \cdot 45$ and $7 \cdot 33$. $P_{50}(7 \cdot 4)$ in these 10 patients ranged from $3 \cdot 1$ to $4.0 \mathrm{kPa}(23 \cdot 3-$ $29.7 \mathrm{~mm} \mathrm{Hg})$. In 10 normal subjects $P_{50}(7 \cdot 4)$ averaged $3.6 \pm$ $0.009 \mathrm{kPa}(26.7 \pm 0.65 \mathrm{~mm} \mathrm{Hg})$ in our hands. The 2,3-DPG levels of our patients correlated with $P_{50}(7 \cdot 4)$ values, varying from 13.2 to $18.9 \times 10^{-6} \mathrm{~mol} / \mathrm{g}$ haemoglobin and in normal subjects averaging $12 \cdot 8 \pm 10^{-6} \times \mathrm{mol} / \mathrm{g}$ haemoglobin.

The measured determinants of oxygen transport are shown in the table. The mixed venous $\mathrm{Po}_{2}\left(\mathrm{P}_{\mathrm{v}} \mathrm{O}_{2}\right)$ was derived as follows: Arterial $\mathrm{Po}_{2}, \mathrm{PcO}_{2}$, and $\mathrm{pH}$ allowed the arterial oxygen saturation $\left(\mathrm{SaO}_{2}\right)$ to be calculated at the measured $\mathrm{P}_{50}$; the oxygen capacity allowed derivation of the arterial oxygen content, and cardiac output and oxygen uptake then led by the Fick principle to the arteriovenous oxygen content difference, and so to the mixed venous oxygen content and saturation. Again using the measured $\mathbf{P}_{50}$ and the $\mathrm{pH}$ measured in the pulmonary arterial (mixed venous) blood sample we calculated the $\mathrm{PrO}_{2}$ by means of the Bohr effect of $-0 \cdot 50$. When the $\mathrm{Pro}_{2}$ value calculated by these methods was compared with that actually measured in the mixed venous blood and also with the value derived from a standard normal binding curve with a $\mathbf{P}_{50}$ of $3.5 \mathrm{kPa}(26.7 \mathrm{~mm} \mathrm{Hg})$ (Severinghaus, 1966) these values did not differ by more than $0.53 \mathrm{kPa}(4 \mathrm{~mm} \mathrm{Hg})$ in any of the patients, which is very close to the $95 \%$ confidence limits of our error of measurement of $\mathrm{Po}_{2}$ in blood, at $\pm 0.47 \mathrm{kPa}( \pm 3.5 \mathrm{~mm} \mathrm{Hg})$ (Flenley et al., 1967).

\section{Discussion}

These observations imply that in our patients, most of whom had chronic stable hypercapnia and compensated respiratory acidosis, spontaneously arising wide variations in 2, 3-DPG concentrations were associated with considerable changes in the position of the binding curve, as measured by $\mathbf{P}_{50}$. Nevertheless, such variations had comparatively little effect on oxygen transport when these patients were breathing air, for both the measured and calculated $\mathrm{P}_{\bar{v} \mathrm{O}_{2}}$ varied by only $0.53 \mathrm{kPa}(4 \mathrm{~mm}$ $\mathrm{Hg}$ ) at most from the value calculated using a standard normal binding curve with a $\mathrm{P}_{50}$ of $3.6 \mathrm{kPa}(26.7 \mathrm{~mm} \mathrm{Hg})$.

The mechanism of this apparent paradox lies in the shape of the binding curve, as shown in fig. 1 , where two curves with a $P_{50}(7.4)$ of 2.7 and $4.0 \mathrm{kPa}(20$ and $30 \mathrm{~mm} \mathrm{Hg})$ are drawn. If we take an $\mathrm{PaO}_{2}$ of $5.3 \mathrm{kPa}(40 \mathrm{~mm} \mathrm{Hg})$ the arterial points are already "over the knee" of the binding curve (fig. 1a). Thus with a slightly wide arteriovenous oxygen content difference of $50 \mathrm{ml} / \mathrm{l}$ - that is, a normal to low cardiac output-the venous points on the curve are relatively close in terms of $\mathrm{P}_{\bar{v}} \mathrm{O}_{2}$ despite the difference in position of the curves as shown by their $P_{50}$ (7.4). As fig. $1 \mathrm{~b}$ shows, however, the same arteriovenous oxygen content difference when the $\mathrm{PaO}_{2}$ is higher-for example, $13.3 \mathrm{kPa}(100 \mathrm{~mm} \mathrm{Hg})$-results in considerable separation of
$\mathrm{PṽO}_{2}$ when the $\mathrm{P}_{50}(7 \cdot 4)$ changes from $2 \cdot 7$ to $4.0 \mathrm{kPa}(20$ to $30 \mathrm{~mm}$ $\mathrm{Hg})$.

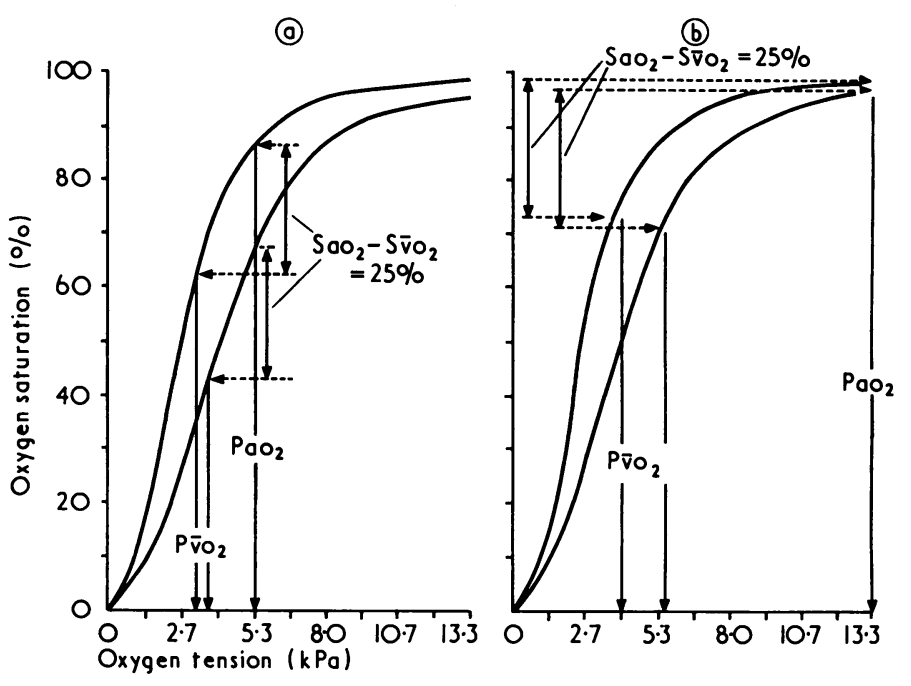

FIG. 1-Oxygen binding curves with $\mathrm{P}_{50}(7 \cdot 4)$ of $2.7 \mathrm{kPa}$ (left curve) and $4.0 \mathrm{kPa}$ (right curve). $\mathrm{PVO}_{2}$ for each curve is shown, assuming arterioand $4.0 \mathrm{kPa}$ (right curve). $\mathrm{PVO}_{2}$ for each curve is shown, assuming arterio-
venous saturation difference $\left(\mathrm{SaO}_{2}-\mathrm{SvO}_{2}\right)$ of $25 \%$, when the arterial $\mathrm{Po}_{2}$ is (a) $5.3 \mathrm{kPa}$ and (b) $13.3 \mathrm{kPa}$.

Conversion: SI to Traditional Units- $\mathrm{kPa} \approx 7.5 \mathrm{~mm} \mathrm{Hg}$.

These interactions between $\mathrm{P}_{50}, \mathrm{PaO}_{2}$, arteriovenous oxygen content difference (inversely related to cardiac output), and the resultant $\mathrm{P}_{\mathrm{v}} \mathrm{O}_{2}$ can be described graphically. The effects of a change in $P_{50}(7.4)$ from 2.7 to $4.0 \mathrm{kPa}(20$ to $30 \mathrm{~mm} \mathrm{Hg})$ on the resultant $\mathrm{P}_{\bar{v} O_{2}}$ at $\mathrm{PaO}^{2} 13.3,9 \cdot 3,6 \cdot 7$, and $5.3 \mathrm{kPa}(100$, 70,50 , and $40 \mathrm{~mm} \mathrm{Hg}$ ) are shown in fig. 2. Arteriovenous oxygen content differences of $40 \mathrm{ml} / 1$ and $60 \mathrm{ml} / 1$ blood are shown. In each case the oxygen capacity was taken as $200 \mathrm{ml} / 1$ blood and the arterial $\mathrm{pH}$ as $\mathbf{7 \cdot 4 0}$.

Clearly changes in $P_{50}(7 \cdot 4)$ have considerable effects on oxygen transport when the $\mathrm{PaO}_{2}$ is high but minimal effects, amounting to only $0 \cdot 26-0 \cdot 40 \mathrm{kPa}(2-3 \mathrm{~mm} \mathrm{Hg})$ differences in $\mathrm{P}_{\mathrm{v}}{ }_{2}$, when the $\mathrm{PaO}_{2}$ is low. Turek et al. (1973) reached a similar conclusion from theoretical studies of the binding curve.

A rise in $P_{50}(7.4)$ from 2.7 to $4.0 \mathrm{kPa}(20$ to $30 \mathrm{~mm} \mathrm{Hg}$ ) could have a considerable effect on blood oxygen transport when a high $\mathrm{PaO}_{2}$ is associated with a low cardiac output-for example, by raising $\mathrm{Pv}_{2}$ from the dangerously low value of $3.7 \mathrm{kPa}(28$ $\mathrm{mm} \mathrm{Hg}$ ) to a near normal value of $5.7(43 \mathrm{~mm} \mathrm{Hg}$ - -without a change in cardiac output. These deductions from the shape of the oxygen binding curve, which provide an explanation for our observations in chronic hypoxaemia, lead us to propose a potentially valuable role for a therapeutically induced rise in $\mathbf{P}_{50}$ in the treatment of cardiogenic or other forms of shock, where the cardiac output is usually low and cannot be increased 
(a)

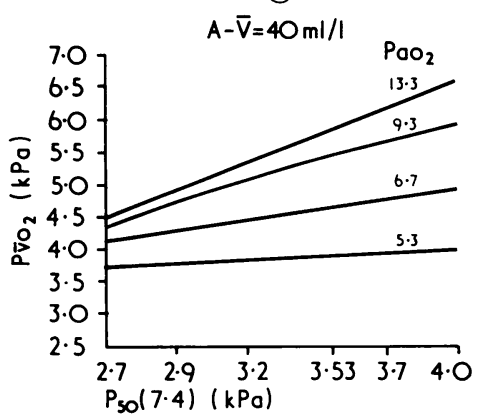

(b)

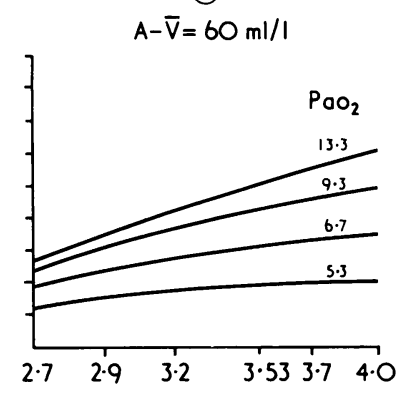
FIG. 2-Calculated relationships between $\mathrm{P}_{50}(7.4)$ and $\mathrm{PvO}_{2}$ for $\mathrm{PaO}_{2}$ of
$13 \cdot 3,9 \cdot 3,6 \cdot 7$, and $5 \cdot 3 \mathrm{kPa}$. Oxygen capacity of $200 \mathrm{ml} / 1$ blood and arterial $\mathrm{pH}$ of 7.40 are assumed. In (a) arteriovenous content difference $(\mathrm{a}-\overline{\mathrm{v}})$ is $\mathrm{pH}$ of $7 \cdot 40$ are assumed.
$60 \mathrm{ml} / \mathrm{l}$ and in (b) $40 \mathrm{ml} / \mathrm{l}$.

Conversion: SI to Traditional Units $-1 \mathrm{kPa} \approx 7.5 \mathrm{~mm} \mathrm{Hg}$.

(McKenzie et al., 1964). If high-concentration oxygen therapy could provide $\mathrm{a} \mathrm{PaO}_{2}$ of around $13.3 \mathrm{kPa}(100 \mathrm{~mm} \mathrm{Hg})$ in such shocked patients the transport of oxygen to the cells of the body could be facilitated by an increase in $P_{50}$, which would then allow oxygen to be delivered with a higher $\mathrm{P}_{\mathrm{v}} \mathrm{O}_{2}$ (fig. 2 b). This would cause an improvement in the $\mathrm{Po}_{2}$ gradient driving diffusion of oxygen from capillaries to the site of oxygen usage in the cellular mitochondria (Flenley, 1967). This suggestion now awaits direct trial when a therapeutic agent to raise $P_{50}$ becomes available.

\section{References}

Benesch, R., and Benesch, E. (1967). Biochemical and Biophysical Research Communications, 26, 162 .

Chanutin, A., and Curnish, R. (1967). Archives of Biochemistry and Biophysics, 121, 96.

Edwards, M. J., and Martin, R. J. (1966). fournal of Applied Physiology, 21, 1898.

Fairweather, L., Walker, J., and Flenley, D. C. (1974). Clinical Science and Molecular Medicine, 47, 577.

Flenley, D. C. (1967). Lancet, 1, 270.

Flenley, D. C., Millar, J. S., and Rees, H. A. (1967). British Medical fournal, 2, 349.

Kilmartin, J. W., and Rossi-Bernardi, L. (1973). Physiological Reviews, 53, 836.

King, E. J., and Wooton, I. D. P. (1956). Microanalysis in Medical Biochemistry, 3rd edn. p. 255. London, Churchill.

Krimsky, I. (1963). In Methods of Enzymatic Analysis, ed. H. U. Bergmeyer, p. 238, New York, Academic Press.

McKenzie, G. J., et al. (1964). Lancet, 2, 825.

Severinghaus, J. W. (1966). Journal of Applied Physiology, 21, 1108.

Turek, Z., Kreuzer, F., and Hoofd, L. J. C. (1973). Pfügers Archiv für die gesamte Physiolegie des Menchen und der Tiere, 342, 185.

Van Slyke, D. D., and Neill, J. M. (1924). Fournal of Biological Chemistry, $61,523$.

\title{
Prolactin Studies in "Functionless"' Pituitary Tumours
}

\author{
D. F. CHILD, S. NADER, K. MASHITER, M. KJELD, L. BANKS, T. RUSSELL FRASER
}

British Medical fournal, 1975, 1, 604-606

\section{Summary}

Hyperprolactinaemia was found in all 17 women and in one out of six men who presented with hypogonadism and a radiologically enlarged sella turcica but no other clinical endocrine dysfunction. Some of the women also had galactorrhoea. The greater the level of hyperprolactinaemia in these 18 patients the larger their sellae turcica except in two patients with unusual features. The sella turcica was usually asymmetrically enlarged and there was rarely an upward extension of tumour, though the sella floor often showed some erosion on tomography. An oral dose of bromocriptine suppressed the hyperprolactinaemia in most patients at the same rate as in normal post-partum women.

Nine of the 18 patients with hyperprolactinaemia had low basal luteinizing hormone (LH) levels. The LH responsiveness to $100 \mu \mathrm{g}$ of LH-releasing hormone (LHRH) was tested in 12, and eight showed subnormal values. Of eight biopsy specimens obtained four showed acidophil granules on light microscopy, and in five granules of various sizes were seen on electron microscopy.

\footnotetext{
Endocrine Unit, Department of Medicine, Royal Postgraduate Medical School, Hammersmith Hospital, London W12 0HS D. F. CHILD, M.B., M.R.C.P., Medical Registrar S. NADER, M.B., M.R.C.P., Medical Registrar K. MASHITER, PH.D., Endocrinologist M. KJELD, M.D., Research Fellow L. BANKS, Radiographer
T. RUSSELL FRASER, M.D., F.R.C.P., Professor in Clinical Endocrinology
}

\section{Introduction}

Amenorrhoea with or without galactorrhoea has long been known to be common in women with radiologically evident pituitary tumours (Forbes et al., 1954), and when there is no associated acromegaly or Cushing's disease it has been customary to refer to these as "functionless" pituitary tumours. Lewis and van Noorden (1974) have commented that not all these tumours are chromophobes histologically, and on both light and electron microscopy the tumours may vary from being inactive to showing intense secretory activity. Thus, histological evidence or serum hormone levels can show that these tumours may not be "functionless".

The frequency of hyperprolactinaemia with these tumours is not precisely known though Jacobs and Daughaday (1973) put it at $30 \%$. Hyperprolactinaemia occurs in some men with functionless pituitary tumours (Thorner et al., 1974), but again its frequency has not been determined. Vezina and Sutton (1974) found that all 20 of their patients with hyperprolactinaemia and associated amenorrhoea and galactorrhoea had radiological evidence of a pituitary tumour after careful tomography, even though a plain $x$-ray examination of the pituitary.fossa showed it to be of normal size in 14 patients. All their patients subsequently had transphenoidal surgery, and pituitary tumours were found in each case.

We report here an analysis of 18 patients with hypogonadism or visual field defects or both who also had hyperprolactinaemia.

\section{Patients and Methods}

Six men and 17 women all presented with hypogonadism or visual field defects or both, and all also had radiologically enlarged sellae. None had received any treatment directed to the pituitary gland. Their clinical features are summarized in the table. All 17 women and one man had hyperprolactinaemia. Eight of these patients were later treated by pituitary implantation of yttrium- 90 . 